\title{
Study on the reproductive behavior among women of rural areas of Pondicherry
}

\author{
K. N. Prasad*, Basavaraj M. Ingalgeri, R. Poovitha, E. Sujitha, K. Sukanya, \\ Thongam BK. Singh, D. Suganya, M. Suganya, V. Viswanath
}

\begin{abstract}
Department of Community Medicine, Shri Lakshmi Narayana Institute of Medical Science, Kudapakkam, Pondicherry-605502, India
\end{abstract}

Received: 17 December 2014

Accepted: 11 January 2015

*Correspondence:

Dr. K. N. Prasad,

E-mail: drknprasad2@gmail.com

Copyright: (C) the author(s), publisher and licensee Medip Academy. This is an open-access article distributed under the terms of the Creative Commons Attribution Non-Commercial License, which permits unrestricted non-commercial use, distribution, and reproduction in any medium, provided the original work is properly cited.

\begin{abstract}
Background: The fertility rate in India is declining and it is necessary to know the factors responsible for such decline in different states. It was decided to study reproductive behavior of women contributing to decline in fertility in Pondicherry. The aim and objective of this study is known the reproductive behavior of women in the rural areas on Pondicherry.

Methods: Sample of 300 married women aged between 30 and 60 years were selected randomly from village belonging to Katerikuppam PHC and the data collected using the pre tested semi open ended questionnaires by interviewing the subjects at their doorsteps during September to November 2014.

Results: The mean age of the subjects was $41.5 \pm 9.5$ years. There were 793 total pregnancies and live births were 701 and abortions accounted for ten percent and still births were 9 in number. The mean number of pregnancies and live births were $2.6 \pm 1.1$ and $2.3 \pm 1.0$ per women respectively. The mean age at menarche, marriage and first pregnancy were $14.3 \pm 1.4,19.6 \pm 3.1$ and $21.1 \pm 3.1$ years respectively. The mean number of pregnancies were declined from currently older age to the lower age of the subjects and found to be statistically significant.

Conclusions: The mean age at marriage and first pregnancy is increasing and the differences in the mean number of pregnancies and live births are showing declining trend.
\end{abstract}

Keywords: Fertility, Behavior, Menarche, Marriage, First pregnancy, Rural, Abortions

\section{INTRODUCTION}

Demography of the country is influenced by the fertility behavior of women in various communities with different cultural practices. The high fertility rates may be associated with the high mortality rate among mothers and children especially infants. Though the fecundity are high among women irrespective of their nutritional status, diseases prevalence, socio economic conditions, practice of family planning methods, fertility status are determined by the age at onset of reproductive phase of life, cultural practices of marriage, conception, occupation, availability and utilisation of $\mathrm{MCH}$ services, survival of the newborn babies, social security measures, gender bias in the society, decision making power at the domestic level. ${ }^{1-4}$

The total fertility rate [TFR, fertility rate, Total Period Fertility Rate (TPFR)] of a population is the number of children a woman would have if she was subject to prevailing fertility rates at all ages from a single given year and survives throughout all her childbearing years. ${ }^{1,2}$ Fertility rate is a better index of fertility than the crude birth rate because independent age structure of the population and a reasonable summary of current fertility levels. The TFR does not necessarily predict how many 
children young women now will eventually have, as their fertility rates in years to come may change from those of older women now. ${ }^{2,45}$ The total fertility rate of India was 5.4 in 1971 in the year and declined by $55 \%$ over the four decades. $^{5}$ The current TFR is 2.5 in 2010 and there are variations in TFR in the country, high among the low socio economics, illiterates and early age at marriage, foeticides, infanticides, male child preferences are present in northern parts of India. ${ }^{5-7}$ The TFR has declined in the southern states of India attributed to better education, occupation, reduction of mortality rates among infants and under five children, availability and utilisation of family welfare service. ${ }^{1,5,7}$

The states like Tamil Nadu and Pondicherry is having TFR rate of 1.7 per women with variation at the district levels. ${ }^{8,9}$ The union Territory of Pondicherry is geographically scattered within the parts of Tamil Nadu and Kerala, hence the fertility rate trends are similar to these states. This study was conducted with an objective to study the reproductive profile among rural women in selected age group of 30 to 60 years in Pondicherry.

\section{METHODS}

The union territory of Pondicherry had got 5 rural districts and ten Primary Health Centers (PHC). Vazhudhavur was selected as study village in the PHC area of Katerikuppam. The sample size of 300 married women were selected for the study during September and October 2014. More than 80 percent of study subjects were homemakers. The investigators collected the data using the pre tested semi open-end questionnaires using the interview technique at the door steps of randomly selected houses. In the some of the houses more than one subject were fulfilled the criteria of becoming eligible for the study and data were collected from them. Information in the questionnaires includes current age of subject, age at menarche, marriage, first pregnancy, number of pregnancies, outcome of each pregnancy, number of live births, abortions, stillbirths, sex of baby, use of family planning methods, interval between pregnancies, approximate gestation period of abortion, etc.

\section{Criteria for selection of the age group}

The conventional international statistical usage age is 15 of 49 years for fertility studies. ${ }^{5,8}$ It is observed that Age Specific Fertility Rates (ASFR) are high among the women whose married life is less than 5 years. Since the age at marriage was relatively high in the present community compared to other parts of the country. As a result it is expected that the more than 95 percent of married women would have completed their family size within 10 years of married life. It will be easy to complete the data from women who were already completed their family size to know the changes in the fertility rate over the decades. Hence the age range from 30 to 60 years was selected in this study. The data also shows the generation gap or time gap.
The data were analysed using the SPSS 15 version statistical software. The proportion, mean, standard deviation, chi square test, student ' $t$ ' test and ANOVA test were applied appropriately.

\section{RESULTS}

This study analysed 300 women of 12437 person years on their reproductive behavior. The average age of women in this study was $41.5 \pm 9.5$ years. There were 793 pregnancies reported by the subjects with their mean number of pregnancy $2.6 \pm 1.1$ per woman.

Table 1 showing the mean number of pregnancies per women was less among the women who are currently aged 30-40 years compared to women aged 46 years and above. The proportion of abortions was ten percent but it was more than the $10 \%$ among the woman currently aged 45 years or less. The proportion of abortions reported was less than among the women currently aged 51 years and above. The differences in the total number of pregnancies resulted in live births and abortions among the subjects were found to be statistically significant $(\mathrm{P}<0.03)$.

Table 1: Distribution of total pregnancies, live births, abortions, stillbirths according to age group.

\begin{tabular}{|llllll|}
\hline $\begin{array}{l}\text { Age } \\
\text { group } \\
\text { (years) }\end{array}$ & $\begin{array}{l}\text { Total } \\
\text { No. of } \\
\text { subject }\end{array}$ & $\begin{array}{l}\text { No. of } \\
\text { pregn- } \\
\text { ancies }\end{array}$ & $\begin{array}{l}\text { Live } \\
\text { births* }\end{array}$ & $\begin{array}{l}\text { Abor- } \\
\text { tions* } \\
(\%)\end{array}$ & $\begin{array}{l}\text { Still } \\
\text { births }\end{array}$ \\
\hline $30-35$ & 111 & 229 & 207 & $22(9.6)$ & 1 \\
\hline $36-40$ & 53 & 132 & 116 & $13(9.8)$ & 3 \\
\hline $41-45$ & 44 & 122 & 104 & $16(13.1)$ & 3 \\
\hline $46-50$ & 36 & 113 & 90 & $12(10.6)$ & 2 \\
\hline $51-55$ & 21 & 70 & 65 & $5(7)$ & 0 \\
\hline $56-60$ & 35 & 127 & 122 & $5(3.9)$ & 0 \\
\hline Total & 300 & 793 & 704 & $80(10.1)$ & 9 \\
\hline
\end{tabular}

$* \chi^{2}$ test, $\mathrm{P}<0.03$

Figure 1 shows the mean number of pregnancies and the mean number of live births were found to higher at the currently aged women of 56-60 years and the gap is narrowing towards the currently aged women of 30-35 years.

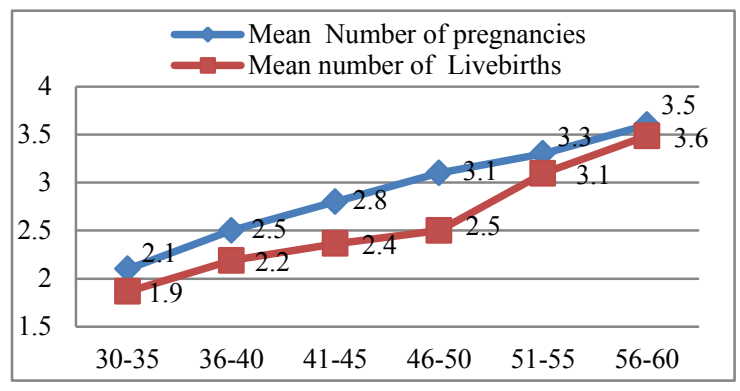

Figure 1: Distribution of mean numbers of pregnancies and the mean number of live births (fertility rate) according to age group. 
Table 2 shows the differences in the number of pregnancies among illiterate women was found to be higher compared to the literate women in this study and is found to be statistically significant $(\mathrm{P}<0.0001)$.

Table 2: Distribution of total pregnancies according to the literacy status and age group.

\begin{tabular}{|lllll|}
\hline $\begin{array}{l}\text { Age } \\
\text { group } \\
\text { (years) }\end{array}$ & $\begin{array}{l}\text { Illiterates } \\
\text { No. }\end{array}$ & $\begin{array}{l}\text { Pregnanci } \\
\text { es in } \\
\text { illiterates* }\end{array}$ & $\begin{array}{l}\text { Literates } \\
\text { No. }\end{array}$ & $\begin{array}{l}\text { Pregnanc } \\
\text {-ies in } \\
\text { literates* }\end{array}$ \\
\hline $30-35$ & 11 & 23 & 100 & 184 \\
\hline $36-40$ & 10 & 23 & 43 & 93 \\
\hline $41-45$ & 13 & 34 & 31 & 70 \\
\hline $46-50$ & 18 & 50 & 18 & 40 \\
\hline $51-55$ & 11 & 35 & 10 & 30 \\
\hline $56-60$ & 22 & 77 & 13 & 45 \\
\hline Total & 85 & 242 & 215 & 462 \\
\hline
\end{tabular}

$* \chi^{2}$ test, $\mathrm{P}<0.0001$

Figure 2 depicts the mean age at menarche, marriage and first pregnancy shows the trends over the period of last 30 years. However the marriage age and first pregnancy age was shifted to higher level during the same period. The mean age menarche was $14.3 \pm 1.4$ years and the mean age at marriage and first pregnancy was observed to be $19.6 \pm 3.1$ and $21.1 \pm 3.1$ years respectively. The differences between the mean age at marriage and mean age at first pregnancy in different age group are found to be statistically significant except for the currently aged 51-55 years.

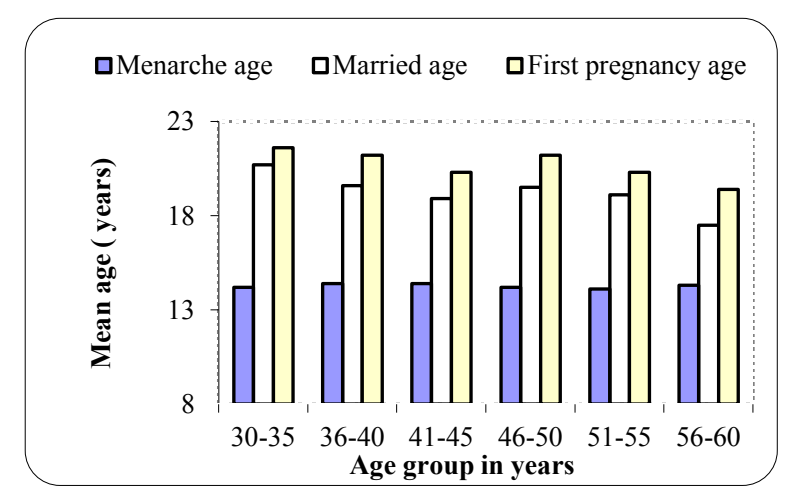

Figure 2: Distribution of Mean age at Menarche, Marriage and first pregnancy according to age group of the subjects.

$\#^{\prime} t$ ' test - Differences between age at marriage and first pregnancy were statistically significant in all age groups except in $51-55$ years $\mathrm{P}<0.05$.

\section{DISCUSSION}

It is well established fact that the fertility rate declining owing to the population and health policies of the Government from the past several years. The education status of women, occupation and change in socio cultural practices in the rural area were attributed for change in the fertility behavior of women. The role of multipurpose health worker (MPHW) or village level health workers in rural areas cannot be ignored or neglected in bringing down the fertility rates in this country though the variations were observed.

The TFR in India in the year 2010 is 2.5 while it is 2.8 in rural and 1.9 in urban areas. TFR was 3.6 in 1991, 2.6 in 2008 with interstate variations in the country. It was 5.4 in 1971 and 2.9 in 2008 in the same rural areas. ${ }^{3,5,8}$ The mean number of Pregnancies and live births per women according to their age group showing the declining trend from the currently aged 56-60 years as shown in the Figure 1. Many studies and reports on the fertility status of the women focus on the conventional age of 15-49 years and their findings are comparable if we consider the women while they were in the reproductive period of life. $^{2,8-10}$

The literacy status is known to influence the fertility behavior of women. In this study the reproductive behavior was analysed with reference to their illiteracy and the mean number of pregnancies were observed to significantly different among different age groups as shown in Table 2. The NFHS survey 3 in the year 20052006 showed the TFR of India was 2.68, rural 2.98 and among illiterates it was $3.5^{5}$

The mean age at menarche is shown to be declining worldwide, however in this study there was no much change noticed as shown in Figure 2. It may be attributed to the biological factors and little chance of error in giving information about their age at menarche. In this society the first menstruation (menarche) event is considered as auspicious and celebrated among the close relatives and friends. As a result the age at menarche cannot be considered as problem in recalling the most important celebrated event in their life. The differences in the mean age at menarche was not statistically significant $(\mathrm{P}>0.05)$.

Prior to the year 1951 the mean age at marriage was 13 years as per the census of India and now it has moved up to 20 years in 2005-2006. Substantial numbers of marriages are held around the age of 16 years in rural areas. ${ }^{2,3,5,8,9,11}$ The mean age at marriage is increasing in this community for the past two decades as in figure 2 . The differences in the mean age at marriage was statistically significant $(\mathrm{P}<0.05)$ and similarly the differences in the mean age at first pregnancies was observed to be statistically significant among the women who completed their family size $(\mathrm{P}<0.05)$. The mean age of fertility in India is $26.5 \pm 5.7$ years and $25.6 \pm 4.4$ years in Tamil Nadu. ${ }^{7,8}$ The teenage marriages are declining everywhere and thus reflect the age at first pregnancies. The important point to be observed in this study is that the differences between the mean age marriage and first pregnancies among women were found to be at least one year. Similar differences were noted in other reports and studies. $8,11-14$ 


\section{Limitations}

The recall on the pregnancies ended in the early abortions, or number of abortions could be difficult for some of the women and it may be underestimated. Similarly mean age of fertility, influence of gender selection bias on fertility rate status and the inter pregnancy interval on fertility were not analysed.

\section{CONCLUSION}

The mean number of pregnancies and the fertility rates are declining over the last three decades. This may be attributed to availability and utilisation of health facilities and awareness about the importance of small family. It is necessary to study in detail about other influencing factors on fertility in this community.

\section{ACKNOWLEDGEMENTS}

Authors are sincerely thanking the study subjects for their co-operation in providing information related to the study. We acknowledge the dean and associate dean for the logistic support given to us during this study.

\section{Funding: No funding sources}

Conflict of interest: None declared

Ethical approval: The study was approved by the institutional ethics committee

\section{REFERENCES}

1. Espenshade TJ, Guzman JC, Westoff CF. The surprising global variation in replacement fertility. Popul Res Policy Rev. 2003;22(5/6):575.

2. Vlossoff $\mathrm{C}$. The status of women in rural India: a village study. Soc Action. 1982 Oct-Dec;32(4):380407.

3. Pramila Rai, Ishwari Sharma Paudel, Anup Ghimire, Paras Kumar Pokharel, Raju Rijal, Surya Raj Niraula. Effect of gender preference on fertility: cross-sectional study among women of Tharu community from rural area of eastern region of Nepal. Reprod Health. 2014;11:15.

4. Vlassoff C. Fertility intentions and subsequent behavior: a longitudinal study in rural India. Stud Fam Plann. 1990 Jul-Aug;21(4):216-25.
5. Park K. The total fertility rate. In: Park K, eds. Park's Text Book of Preventive and Social Medicine. 22nd ed. Jabalpur, Madhya Pradesh, India: Banarsidas Bhanot Publishers; 2013: 449-452.

6. Peabody. John Hopkins University, people report, Baltimore, Maryland, Sep-Oct 1985: 225-245. Available at: www.peabody.jhu.edu.

7. Registrar General of India. Sample Registration System statistical report 2010. In: RGI, eds. Ministry of Home affairs, Government of India, Report of 1 of 2012. India: GOI; 2013: 30-66.

8. Census of India. Estimates of fertility indicators. In: GOI, eds. Census India. India: Government of India, Ministry of Home affairs; 2012: 29-38.

9. Brigitte Bruun Nielsen, Jerker Liljestrand, Morten Hedegaard, Shakuntala Haraksingh Thilsted, Abraham Joseph. Reproductive pattern, perinatal mortality, and sex preference in rural Tamil Nadu, South India: community based, cross sectional study. BMJ: Br Med J. 1997;314(7093):1521-4.

10. Dharmalingam A. The social context of family size preferences and fertility behaviour in a South Indian village. Genus. 1996;52:83-103.

11. Shankar Nath Jha, Baijayanti Baur, Anima Haldar, Urmila Dasgupta. A study on fertility perception: an experience from West Bengal, India. Stud Fam Plann. 1990 Jul-Aug;21(4):216-25.

12. Nath DC, Leonetti DL. Correlates of coital patterns in a traditional Indian society. In: Yadava RC, eds. Dynamics of Population Change: Emerging Issues of 21st Century. New Delhi: Shipra Publication; 2001: 57-67.

13. Garenne M. Sex ratios at birth in African populations: a review of survey data. Hum Biol. 2002;74:889-900.

14. Nath DC, Singh B. Impact of son preference on fertility indices in Manipur. Intern J Manag Econ Soc Sci. 2012;1:26-32.

DOI: $10.5455 / 2320-1770 . i j r \operatorname{cog} 20150233$

Cite this article as: Prasad KN, Ingalgeri BM, Poovitha R, Sujitha E, Sukanya K, Singh TBK, Suganya D, Suganya M, Viswanath V. Study on the reproductive behavior among women of rural areas of Pondicherry. Int J Reprod Contracept Obstet Gynecol 2015;4:185-8. 